\title{
Assessing oil sands tailings consolidation using a modified benchtop filter press
}

TH Qureshi Northern Alberta Institute of Technology, Canada

Y Li Northern Alberta Institute of Technology, Canada

A Sedgwick Northern Alberta Institute of Technology, Canada

H Kaminsky Northern Alberta Institute of Technology, Canada

J Ng Northern Alberta Institute of Technology, Canada

\begin{abstract}
Open pit surface mining generates process effluents known as tailings. These mixtures accumulate in large impoundment structures typically termed as tailings ponds, which serve as storage structures where water from the tailings is separated and recycled back into the process. With the continuous accumulation of material in tailings ponds, and to comply with reclamation and water-use regulations, the industry is constantly seeking new technologies that can accelerate the tailings consolidation and dewatering process. Preliminary tools and techniques to screen potential consolidation technologies are valuable to quickly understand the effectiveness of the technology on the bench-scale before larger-scale testing. At present, settling tests have been the ideal medium for bench-scale study, however, this process can be time-intensive. This study compares a potential tool for short-term testing of consolidation, a benchtop filter press, with a standard settling test. The benchtop filter press is commonly used for the generation of specific resistance to filtration (SRF) data, however, the application for use in understanding consolidation is not. In this study, a benchtop filter press was modified to remove the limitation on the dewatering time due to the filter cake cracking, thus allowing dewatering past the liquid limit of the material. Two types of synthetic tailings were developed using a kaolinite and bentonite mix in synthetic process water, with varying solids content, methylene blue indices (MBI) and water chemistries, to mimic the conditions in actual mining samples.

The study shows that the modified benchtop filter press results produce similar trends to settling tests and perform as expected with and without polymer addition. The modified benchtop filter press provides data in a course of hours to days, as compared to the settling test data that can take weeks to months to generate. Additionally, work conducted with oil sands fluid fine tailings (FFT) after various treatments, demonstrates that SRF curves from actual mining samples show trends in dewatering time consistent with observed field performance.
\end{abstract}

Keywords: consolidation, measurement, specific resistance to filtration

\section{Introduction}

In mining and mineral processing, waste by-products are often produced in the form of high-density slurries. High-density slurries are mixtures consisting of fine solids suspended in a liquid phase. These fines naturally separate out of the liquid phase after long periods of time in a quiescent state, resulting in both environmental and economic impact (Patterson 2004). An example of high-density slurry is oil sands tailings, which is a by-product of the Clark hot water extraction process from surface mining of the Athabasca oil sands in Alberta, Canada. These tailings have non-settling behaviour and consist of water, sand, silts, clay, and residual bitumen. The tailings are accumulated in large storage facilities known as tailings ponds (Canadian Association of Petroleum Producers n.d.; Natural Resources Canada 2016). 
While the sand portion of fluid fine tailings (FFT) settles quickly to the bottom of the pond, the fines and clays stay in suspension within the water. Later, as the layers get deeper, they develop into mature fine tailings (MFT) which have a long-term consolidation (Alberta Energy Regulator 2019). As a result, the fines and clays in MFT can take decades to settle at the bottom of the layers. As of 2018 , there are $1,253 \mathrm{Mm}^{3}$ of fluid tailings accumulated in these tailings ponds (Alberta Energy Regulator 2019). As per regulations in place, oil sands producers are required to reclaim tailings ponds within 10 years of their operation end date (Alberta Energy Regulator 2017; Government of Alberta 2015). To reduce fluid tailings volumes and meet the reclamation objectives, tailings treatment processes often focus on accelerating the separation of water from the fine clay particles in tailings (Canada's Oil Sands Innovation Alliance n.d.-a, Canada's Oil Sands Innovation Alliance n.d.-b; Suncor n.d.).

Coagulation allows consolidation, as fine particles settle and separate from the water-based mixture (Vietti 2018, pp. 64-65). According to the double-layer (DLVO) theory, the electrical double layer of a fine clay particle is the main phenomenon that causes the stability of fine clays in solution resulting in very slow separation of fines from water in tailings. The interaction of the double layer with Van der Waals force of attraction explains the dispersive behaviour of fluid tailings, where the fine particles stabilise in solution through the electrostatic double layer. The coagulation of fine particles helps the fine particles to settle (Vietti 2018, pp. 64-65). The methylene blue index (MBI) shows the capability of a material to hold on to charged particles, where a higher MBI suggests the material can hold on to more water due to a larger double layer. This water is called bound water, which is a concern for dewatering (Kaminsky 2014, pp. 1-5). Another method to accelerate tailings consolidation is by the addition of polymeric flocculants, which adsorb and bridge the fine particles into larger flocs that separate from the water phase (SNF Floerger n.d.).

To evaluate tailings consolidation performance, the current industry standard is the cylinder settling test, which is a bench-scale experiment that can be performed to study the effects of water chemistry, chemical additions, as well as process aids (Vietti 2018, p. 67-69). Although settling tests can provide useful information, they are time consuming and require dedicated lab space. Also, the setup, data collection, and glassware cleaning are labour intensive (Guang et al. 2016). Variations in temperature, sampling and agitation techniques, dimensions of settling columns, and time between sampling and start of determination are also known to affect the settling results, making a comparison of settling data found in literature impractical (Environmental Business Specialists n.d.).

In this study, a six-unit modified benchtop filter press was used to perform the specific resistance to filtration (SRF) test and generate data used to evaluate tailings consolidation performance (Figures 1a, 1b and 1c).
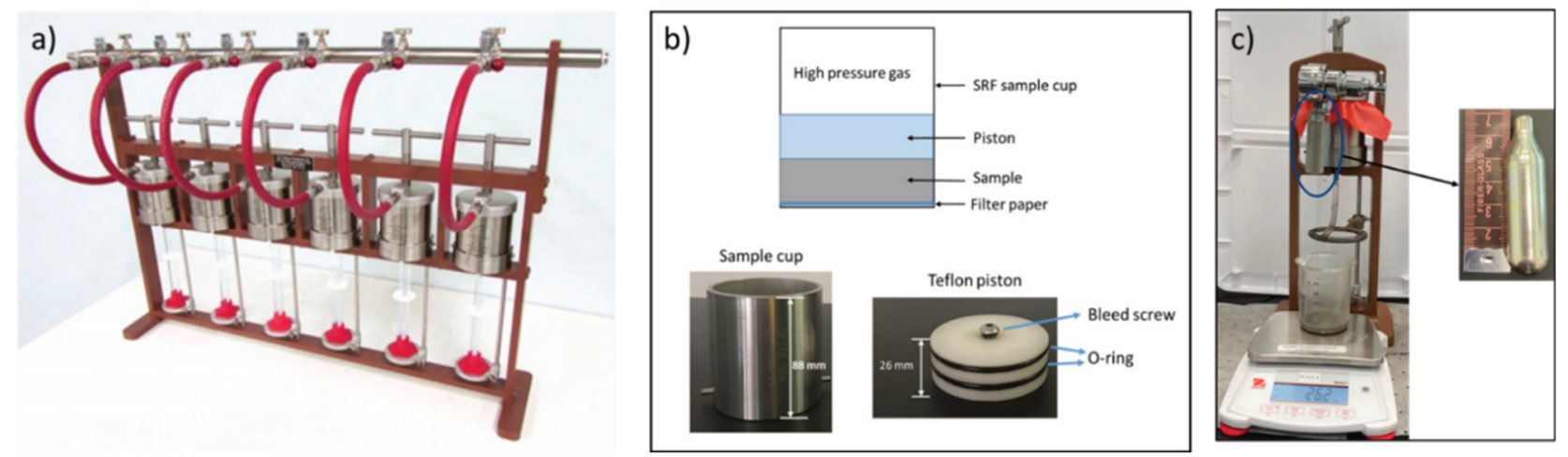

Figure 1 Benchtop filter press setup. (a) Six-unit benchtop filter press (adopted from OFITE website); (b) Schematic of modified filter press setup; (c) Individual filter press setup using $\mathrm{CO}_{2}$ bulb for pressure filtration. Source: OFITE (2013)

Firstly, synthetic tailings analogues were used to compare the SRF test with the industry standard settling test to determine if a correlation exists. To determine if the SRF test can show trends with process aids, a polymer was used with the analogue tailings and compared to the no-treatment baseline. Finally, the SRF test was performed using actual oil sands tailings (Li et al. 2018). At each stage, the SRF test measured the 
sediment cake's resistance to the liquid being forced out by the dewatering process (Lu 2016). Once a homogenised sample of $300 \mathrm{~g} \pm 0.1 \mathrm{~g}$ was loaded onto the cell assembly and attached to a manifold, forced air/nitrogen (from a compressed gas cylinder) was pumped into the system at a pressure of $100 \mathrm{psi}$. With a piston in place and a graduated cylinder underneath the cell, the filter press pushed water out into the graduated cylinder. The volume of water was manually recorded as a function of time, allowing a comparison in the ease of dewatering between samples. The use of SRF in estimating sludge dewaterability is not new, however, the modified filter press utilises pistons and/or an elastic bladder to prevent cracking in the cake commonly encountered in the conventional SRF arrangement (Li et al. 2018).

\section{$2 \quad$ Materials and methods}

\subsection{Materials}

In the preliminary stage of testing, two synthetic process waters (SPWs) were prepared as $0.02 \mathrm{M}$ (mol/L) calcium chloride dihydrate $\left(\mathrm{CaCl}_{2} \cdot 2 \mathrm{H}_{2} \mathrm{O}\right)$ and $0.01 \mathrm{M}$ sodium chloride $(\mathrm{NaCl})$ in ultrapure deionised water $(18.2 \mathrm{M} \Omega-\mathrm{cm})$ to simulate coagulating and non-coagulating/dispersive water chemistries, respectively. Both SPWs were corrected to a pH of 8.5 using diluted acids/bases to mimic typical conditions found in oil sands tailings ponds (Li et al. 2018, p. 2). Synthetic tailings analogues were prepared to two solids contents: $0.5 \mathrm{wt} . \%$ and 25 wt.\% solids. For $25 \%$ solids, the SPW was combined with solids in a ratio of one part solid to three parts SPW. For $0.5 \%$ solids, the SPW was combined in a ratio of one part solid to 199 parts SPW. Both percent solids and $\mathrm{MBI}(4.6$ and $13.3 \mathrm{meq} / 100 \mathrm{~g}$ ) were determined by adjusting the ratio of kaolinite and bentonite solids and mixing with the prepared SPWs as shown in Table 1 . Bentonite has a high MBI of $102 \mathrm{meq} / 100 \mathrm{~g}$ and kaolinite (Polygloss 90) has a low MBI of 3 meq/100 g (Kaminsky 2014, p. 4). The MBIs of the clays were checked initially to ensure the correct range. The particle size distribution (PSD) of kaolinite and bentonite clays were measured in triplicate via a laser particle size analyser (Horiba LA-950) following the COSIA method (Canada's Oil Sands Innovation Alliance 2016). The median particle size (i.e. $d_{50}$ ) is 0.29 and $6 \mu \mathrm{m}$ for kaolinite and bentonite, respectively.

Table 1 Composition of substrates to prepare synthetic tailings analogues

\begin{tabular}{|c|c|c|c|c|c|}
\hline $\begin{array}{l}\text { Percent } \\
\text { solids }\end{array}$ & Mass prepared (g) & SPW type (M) & $\begin{array}{l}\mathrm{MBI} \\
\text { (meq/100 g) }\end{array}$ & $\begin{array}{l}\text { Mass of } \\
\text { bentonite }(\mathrm{g})\end{array}$ & $\begin{array}{l}\text { Mass of } \\
\text { kaolinite (g) }\end{array}$ \\
\hline $25 \%$ & Per 4,000 g sample & $\begin{array}{l}0.02 \mathrm{M} \text { calcium chloride } \\
\text { dihydrate }\end{array}$ & 4.6 & 20.62 & 979.38 \\
\hline $25 \%$ & Per 4,000 g sample & $0.01 \mathrm{M}$ sodium chloride & 4.6 & 20.62 & 979.38 \\
\hline $25 \%$ & Per 4,000 g sample & $\begin{array}{l}0.02 \mathrm{M} \text { calcium chloride } \\
\text { dihydrate }\end{array}$ & 13.3 & 123.71 & 876.29 \\
\hline $25 \%$ & Per 4,000 g sample & $0.01 \mathrm{M}$ sodium chloride & 13.3 & 123.71 & 876.29 \\
\hline $0.5 \%$ & Per 1,000 g sample & $\begin{array}{l}0.02 \mathrm{M} \text { calcium chloride } \\
\text { dihydrate }\end{array}$ & 4.6 & 0.10 & 4.90 \\
\hline $0.5 \%$ & Per 1,000 g sample & $0.01 \mathrm{M}$ sodium chloride & 4.6 & 0.10 & 4.90 \\
\hline $0.5 \%$ & Per 1,000 g sample & $\begin{array}{l}0.02 \mathrm{M} \text { calcium chloride } \\
\text { dihydrate }\end{array}$ & 13.3 & 0.62 & 4.38 \\
\hline $0.5 \%$ & Per 1,000 g sample & $0.01 \mathrm{M}$ sodium chloride & 13.3 & 0.62 & 4.38 \\
\hline
\end{tabular}

In the second stage of testing, $0.45 \mathrm{wt}$.\% polymer solutions were prepared in the two different SPWs using a low-mid molecular weight anionic polyacrylamide/polyacrylate copolymer (BASF 1176). The flocculated 
synthetic tailings in the second stage of testing are made in jar testers at optimal dosage $(1,800 \mathrm{~g} / \mathrm{t})$ for inline thickening following the 4" cup method (Sadighian et al. 2018).

For the final stage of testing, industrial FFT samples were used and characterised by Dean and Stark (D\&S) for bitumen, solids, and water content (Dean \& Stark 1920), MBI (Omotoso \& Morin 2008), fines content by $44 \mu \mathrm{m}$ sieving, $\mathrm{pH}$, density, and conductivity (Table 2). Flocculation tests following the 6" $(15.24 \mathrm{~cm})$ cup method (Sadighian et al. 2018) were performed using an anionic polyacrylamide A3338 provided by SNF Canada. The polymer solution was prepared at a concentration of $0.45 \mathrm{wt} . \%$ in pond effluent water (PEW). The high calcium hydrated lime was provided by Graymont Inc.

Table 2 FFT characterisation on composition, MBI, fines content, pH, density, and conductivity

\begin{tabular}{llllllll}
\hline $\begin{array}{l}\text { Mineral \% } \\
\text { by weight }\end{array}$ & $\begin{array}{l}\text { Bitumen \% } \\
\text { by weight }\end{array}$ & $\begin{array}{l}\text { Water \% } \\
\text { by weight }\end{array}$ & $\begin{array}{l}\text { MBI } \\
(\mathbf{m e q} / \mathbf{1 0 0} \mathbf{g})\end{array}$ & $\begin{array}{l}\text { Fines \% by } \\
\text { weight }\end{array}$ & $\begin{array}{l}\text { Density } \\
\left(\mathbf{k g} / \mathbf{m}^{3}\right)\end{array}$ & $\begin{array}{l}\text { Electronic conductivity } \\
(\mathbf{m S} / \mathbf{c m})\end{array}$ \\
\hline 24.7 & 1.2 & 73.6 & 14.1 & 92.8 & 8.50 & 1.184 & 1,370 \\
\hline
\end{tabular}

\subsection{Methods}

The synthetic tailings were prepared by adding the clay minerals in the aforementioned ratios to SPW while mixing using an overhead mixer with a 6 " flat blade at $250 \mathrm{rpm}$ and then mixing for 45 minutes or further until the torque was stable. Next, the settling tests were set up by transferring slurries immediately into $1,000 \mathrm{~mL}$ graduated cylinders, which were then agitated using a plunger with six plunges in 12 seconds (one plunge per two seconds). Figure $2 \mathrm{a}$ shows the settling setup, Figure $2 \mathrm{~b}$ shows the distinct settling column plunger used at Northern Alberta Institute of Technology (NAIT) for settling tests, and Figure $2 \mathrm{c}$ shows the camera setup used to record the settling tests conducted.

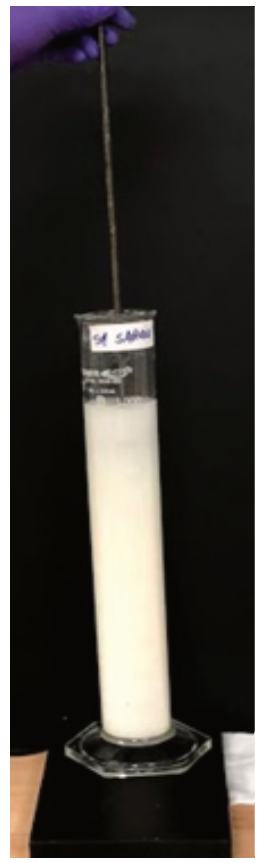

(a)

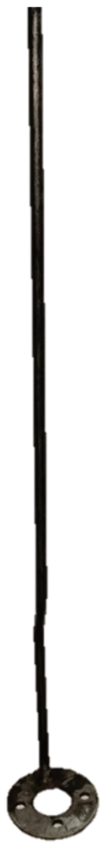

(b)

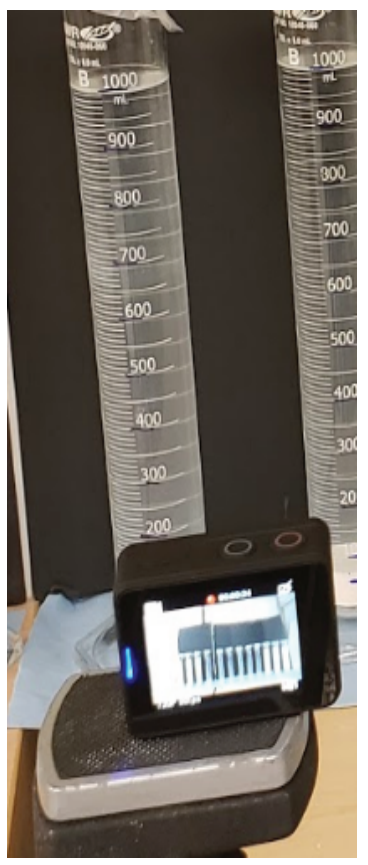

(c)

Figure 2 (a) Settling test setup; (b) Settling plunger; (c) Settling camera setup. Source: Qureshi et al. (2019)

The mudline (i.e. the position of the interface between the supernatant and solids) was recorded and tracked over the course of eight weeks. For the settling tests data, the initial settling rate (ISR) is determined from the initial portion of the normalised mudline height-time plot (Equation 1).

$$
\text { ISR }\left(\frac{m}{h r}\right)=\text { Linear slope from graph } \times \text { Cylinder height }(m) \times \frac{60 \mathrm{~min}}{1 \mathrm{hour}}
$$


For the preliminary stage SRF tests, the samples were prepared in 1,000 g batches as per Table 1 . For SRF testing, mass of $300 \mathrm{~g}$ was subsampled from the 1,000 g batch into the modified SRF cup and the piston inserted, the test was run by applying 100 psi pressure to the manifold, and volume of release water from filter press was recorded overtime until water ceased coming off the filter press.

The goal of the second stage was to test whether the polymers had an effect on dewatering rate measured by the SRF. To test this, the most challenging to settle synthetic tailings streams ( 25 wt.\% solids and MBI 13.3 in SPW1 and SPW2) were flocculated using a low-mid molecular weight anionic polyacrylamide/polyacrylate (BASF 1176). A $300 \mathrm{~g}$ sample of the synthetic tailings was added to a 4" flocculation cup and the polymer added in increments according to the 'water release potential test' for high-density slurry (Sadighian et al. 2018). The optimal dosage was $1,800 \mathrm{~g} / \mathrm{t}$ on a solids basis for both water chemistries (Sadighian et al. 2018).

Once flocculation was complete, the samples were left inside the mixing cup for 20 minutes before decanting off release water. The rest of the flocculated mixture was then transferred to the SRF cell setup. As in stage one, the piston was inserted, and a pressure of 100 psi was applied to the manifold. To retain the solids, Whatman \#50 hardened low ash filter media was used (Ofite 2021). The volume of further water release was monitored as a function of time.

It is important to note, to keep the test fair when making SRF graphs, the volume of polymer added was subtracted from the total mass of the sample and polymer present before decanting, and SRF testing. Also, the water release wait time of 20 minutes in the cup was used as part of the SRF test curves, where the zero-minute point in each curve starts as soon as the polymer is completely added to the sample, and the 20-minute point on the graph indicates the time when the sample is transferred to SRF cup, and the test is started. The reason for including the pre-SRF wait time is to ensure the amount of water release is taken into consideration to show the full effect of polymer versus no polymer addition. Figure 3 shows the process flow diagram of second stage (polymer SRF) testing.

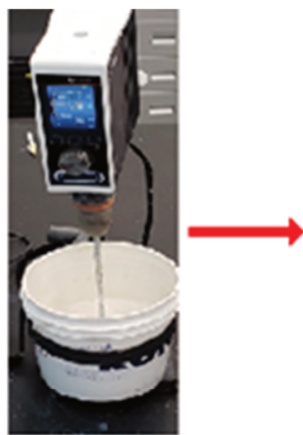

Make the Slurry

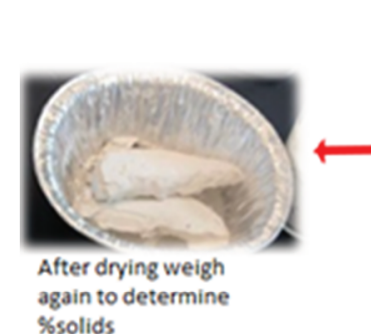
again to determine \%solids

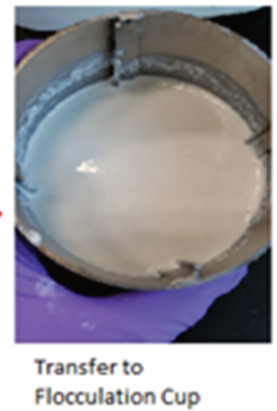

Flocculation Cup

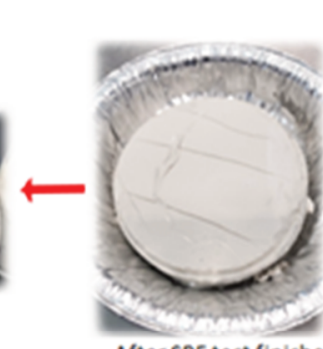

After SRF test finishes Put cake on preweighed pan and put in oven to dry

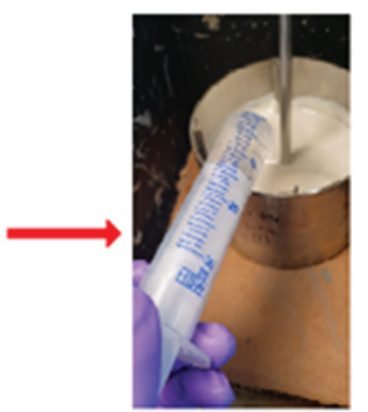

Add polymer

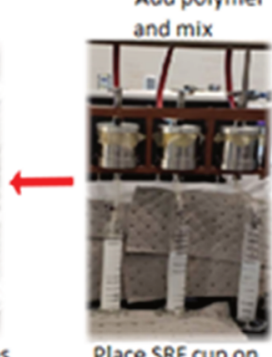

Place SRF cup on Filter Press

and start SRF test

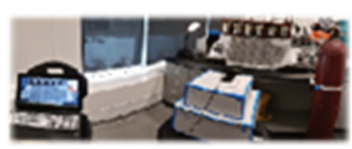

Makeshift Webcam Recorder used to record long term SRF testing

volume vs, time

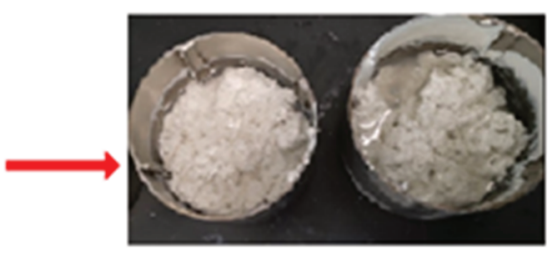

Wait $20 \mathrm{~min}$. in cup
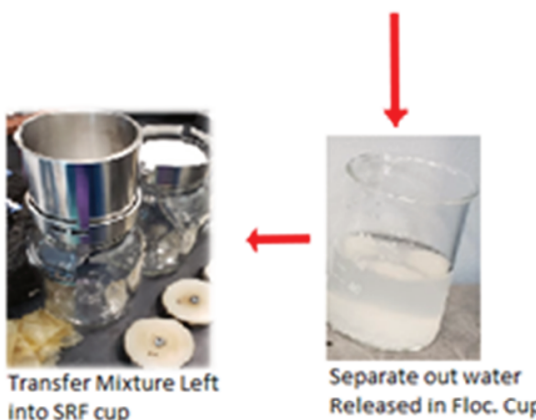

Figure 3 Flow diagram of second stage SRF test with benchtop filter press. Source: Qureshi et al. (2019) 
The SRF was calculated as a measure of the sediment cake's resistance to the liquid being forced out by the dewatering process (Lu 2016). Assuming the cake is incompressible at constant pressure drop, the integrated form of Darcy's filtration equation with boundary conditions of $\mathrm{V}=0$ at $\mathrm{t}=0$ can be expressed by:

$$
\frac{t}{V}=\frac{\mu_{f} c S R F}{2 A^{2} \Delta P} V+\frac{\mu_{f} R_{m}}{A \Delta P} w
$$

and the slope (b) of the $t / V$ versus $V$ plot can be used to determine the SRF:

$$
\mathrm{SRF}=\frac{2 \mathrm{~A}^{2} \Delta \mathrm{P}}{\mu_{\mathrm{f}} \mathrm{c}} \mathrm{b}
$$

where:

$$
\begin{aligned}
& \text { SRF }=\text { specific resistance to filtration }(\mathrm{m} / \mathrm{kg}) . \\
& \Delta \mathrm{P} \quad=\text { pressure drop }=100 \mathrm{psi}=68,9476 \mathrm{~Pa} . \\
& \mathrm{R}_{\mathrm{m}} \quad=\text { the resistance of filter medium. } \\
& A \quad=\text { area of filter in } \mathrm{m}^{2}=50.27 \times 10^{-4} \mathrm{~m}^{2} . \\
& \mu_{\mathrm{f}} \quad=\text { viscosity of filtrate }=1 \times 10^{-3} \mathrm{~Pa} \cdot \mathrm{s} \text { (viscosity of filtrate). } \\
& \mathrm{c} \quad=\text { the mass of dry cake solids per filtrate volume in } \mathrm{kg} / \mathrm{m}^{3} . \\
& \mathrm{b} \quad=\text { slope of } \mathrm{t} / \mathrm{V} \text { versus } \mathrm{V} \text { plot. }
\end{aligned}
$$

Another necessary measure to understand trends present in the settling test data is percent (\%) solids versus time, which was determined using Equation 4.

Equation 4 for calculating percent solids at a given time. Adapted from Zink (2019).

$$
\% \text { solids }=\frac{\text { Dry mass of solids in mixture }}{(\text { Total mass of sample }- \text { mass of water released })} \times 100 \%
$$

The assumption in Equation 4 is that the volume released, in $\mathrm{mL}$ of water, is the volume of water only. Therefore, using the density of water as $1 \mathrm{~g} / \mathrm{ml}$, we assume that $1 \mathrm{ml}=1 \mathrm{~g}$ of water (United States Geological Survey n.d., para. 2). Therefore, the percent solids for all $25 \%$ solids samples at zero minutes is $250 \mathrm{~g}$ solids $/(1,000 \mathrm{~g}$ total mass $-0 \mathrm{~g}$ water release $) \times 100 \%=25 \%$ solids. The volume of water released is determined by subtracting the initial volume from the current volume at a given time. For example, where the liquid-solid interface is at $970 \mathrm{ml}$ and the initial volume is $1,000 \mathrm{ml}$, then the volume of water released $=1,000-970 \mathrm{ml}=30 \mathrm{ml}$ at that given time. Then, using the data collected of the volume of water (filtrate) released versus time, a solids percent versus time graph can be generated.

In the final stage of testing, the FFT flocculation was performed. An overhead mixer with an online torque sensor and display (Heidolph Hei-Torque 100 Precision Base) was used for the flocculation in a 6" metal baffled cup. Each flocculation was conducted using one litre of FFT sample. The polymer A3338 solution (0.45 wt.\%) was injected into the FFT sample using a peristaltic pump at a fixed flow rate of $1,200 \mathrm{ml} / \mathrm{min}$ at $300 \mathrm{rpm}$ of mixing. Mixing was continued at $300 \mathrm{rpm}$ while monitoring torque response on the overhead mixer screen. When torque reaches a peak value and begins to decrease, the mixing speed was immediately decreased to $50 \mathrm{rpm}$. The flocs are conditioned by mixing at $50 \mathrm{rpm}$ for 15 seconds. For lime treatment on FFT, lime slurry was introduced into the untreated FFT at $100 \mathrm{rpm}$ of mixing and mixing was continued for one minute after lime addition. The flocculated FFT was allowed to release water for 30 minutes and the release water was removed by a graduated pipette. Then the lime slurry was added to the flocculated FFT at $20 \mathrm{rpm}$ of mixing and the combined samples were mixed for one minute after lime addition. These samples were then tested using the filter press setup as per the previous stage of testing. 


\subsection{Testing criteria}

A full factorial design of experiment was carried out using both $1 \mathrm{~L}$ settling tests and $300 \mathrm{~g}$ SRF tests using synthetically made tailings. The factors investigated were solid's concentration ( 0.5 and $25 \%), \mathrm{MBI}(4.6$ and 13.3), and water chemistry ( $\mathrm{NaCl}$ versus $\mathrm{CaCl}_{2} \cdot 2 \mathrm{H}_{2} \mathrm{O}$ ). To understand the effect of each factor, only one factor was changed while the other factors were kept constant. For both settling and SRF testing, each condition was tested in triplicates to ensure data repeatability. In the preliminary testing stage, the goal was to compare the SRF with the settling tests confirming if both showed dewatering consistent with predictions from DLVO theory (i.e. low solids faster than high solids, $\mathrm{CaCl}_{2} .2 \mathrm{H}_{2} \mathrm{O}$ porewater faster than $\mathrm{NaCl}$ porewater, and lower clay content faster than high clay content).

In the second stage, the goal was to investigate the impact of polymer addition on synthetic tailings, particularly for test conditions mimicking a high clay activity FFT ( $25 \%$ solids, MBI of 13.3 , both water SPWs) on the filter press (SRF). In the final stage of testing, FFT harvested from an oil sands tailings pond was analysed on the filter press (SRF) under different polymer and coagulant conditions.

\section{Data and results}

\subsection{Preliminary stage: settling test}

As expected, the settling data did show results consistent with DLVO theory. From the relative comparison drawn from Table 3 and Figures 4-9, it is shown that water chemistry had the greatest impact on the initial settling rate (ISR). With the $0.02 \mathrm{M}$ calcium chloride dihydrate (coagulating) water chemistry, the synthetic tailings ( $0.5 \%$ solids, $\mathrm{MBI}$ of 4.6 and 13.3 ) settled $\sim 4$ orders of magnitude faster compared to the $0.01 \mathrm{M}$ sodium chloride (dispersive) water chemistry. The impact of water chemistry is most prominent when considering the fastest settling test ( $\mathrm{MBI} 4.6$, coagulating chemistry, $0.5 \%$ solids) which is $\sim 5$ orders of magnitude faster than the slowest settling test (MBI 13.3, dispersive chemistry, $25 \%$ solids). Although the impact of water chemistry on $25 \%$ solids synthetic tailings is not as prominent as $0.5 \%$ solids, the coagulating water chemistry still induced faster settling than dispersive water chemistry by a factor of three, at an MBI of 4.6. Coagulating water chemistry is $\sim 1$ order of magnitude faster than dispersive water chemistry when considering $25 \%$ solids, and an $\mathrm{MBI}$ of 13.3 .

Table 3 Initial settling rate data relative comparison (in orders of magnitude and factors) to slowest settling test in each circumstance

\begin{tabular}{|c|c|c|c|c|c|c|}
\hline MBI & Solids & $\begin{array}{l}\mathrm{CaCl}_{2} \cdot 2 \mathrm{H}_{2} \mathrm{O} \\
\text { relative to } \\
\mathrm{NaCl}\end{array}$ & $\begin{array}{l}\mathrm{MBI} \\
\text { comparison } \\
\mathrm{NaCl}\end{array}$ & $\begin{array}{l}\mathrm{MBI} \\
\text { comparison } \\
\mathrm{CaCl}_{2} \cdot 2 \mathrm{H}_{2} \mathrm{O}\end{array}$ & $\begin{array}{l}\text { Solids content } \\
\text { comparison } \\
\mathrm{NaCl}\end{array}$ & $\begin{array}{l}\text { Solids content } \\
\text { comparison } \\
\mathrm{CaCl}_{2} \cdot 2 \mathrm{H}_{2} \mathrm{O}\end{array}$ \\
\hline 4.6 & $25 \%$ & Factor of 3 & Factor of 3 & Factor of 1 & Factor of 1 & Factor of 1 \\
\hline 13.3 & $25 \%$ & $\begin{array}{l}1 \text { order of } \\
\text { magnitude }\end{array}$ & Factor of 1 & Factor of 1 & Factor of 1 & Factor of 1 \\
\hline 4.6 & $0.5 \%$ & $\begin{array}{l}4 \text { orders of } \\
\text { magnitude }\end{array}$ & Factor of 1 & Factor of 1 & Factor of 1 & $\begin{array}{l}4 \text { orders of } \\
\text { magnitude }\end{array}$ \\
\hline 13.3 & $0.5 \%$ & $\begin{array}{l}4 \text { orders of } \\
\text { magnitude }\end{array}$ & Factor of 1 & Factor of 1 & Factor of 2 & $\begin{array}{l}4 \text { orders of } \\
\text { magnitude }\end{array}$ \\
\hline
\end{tabular}

The settling tests were slow for the sodium chloride water chemistry, taking more than 670 hours to collect data for both 0.5 and $25 \%$ solids tests to determine the initial settling rate. However, the $0.5 \%$ solids tests for the $\mathrm{CaCl}_{2} .2 \mathrm{H}_{2} \mathrm{O}$ chemistry took only 0.5 hours for the ISR; hence Figures 5 and 8 have time in minutes, whereas Figures 4, 6, 7, 9 are in hours. 


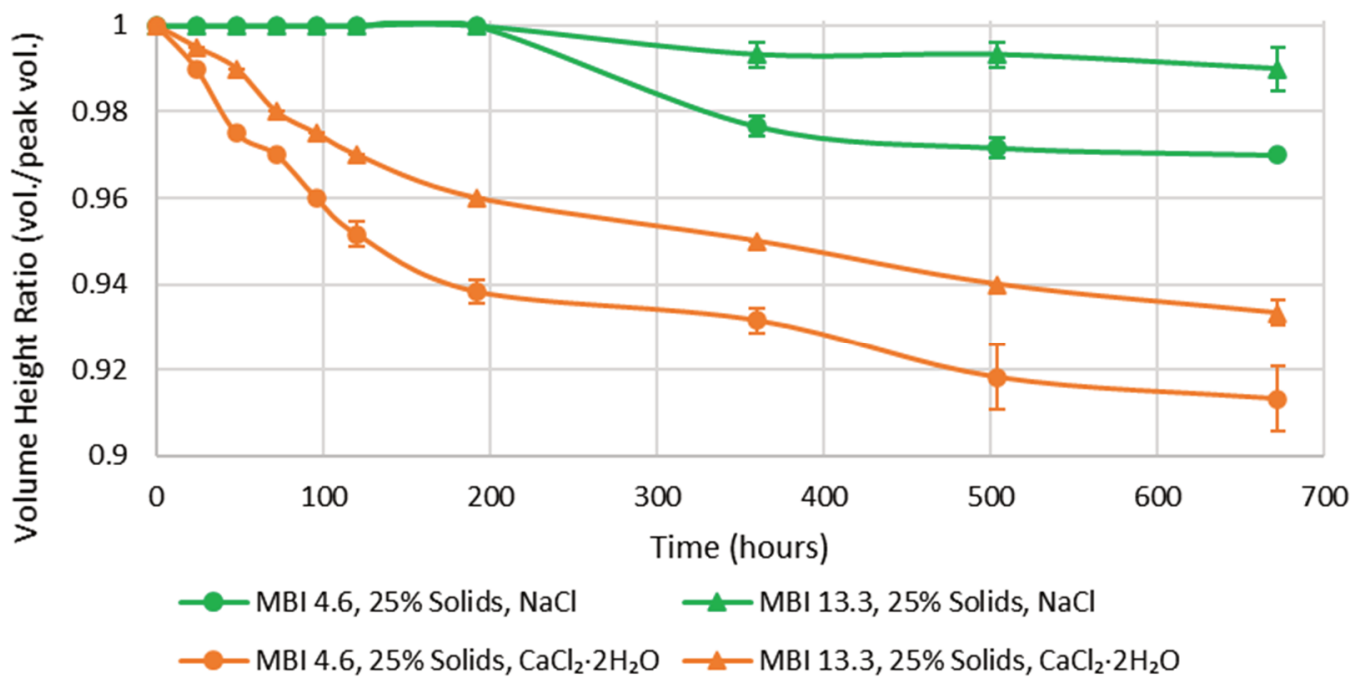

Figure 4 Average volume height ratio versus time. Preliminary stage $25 \%$ solids, settling tests

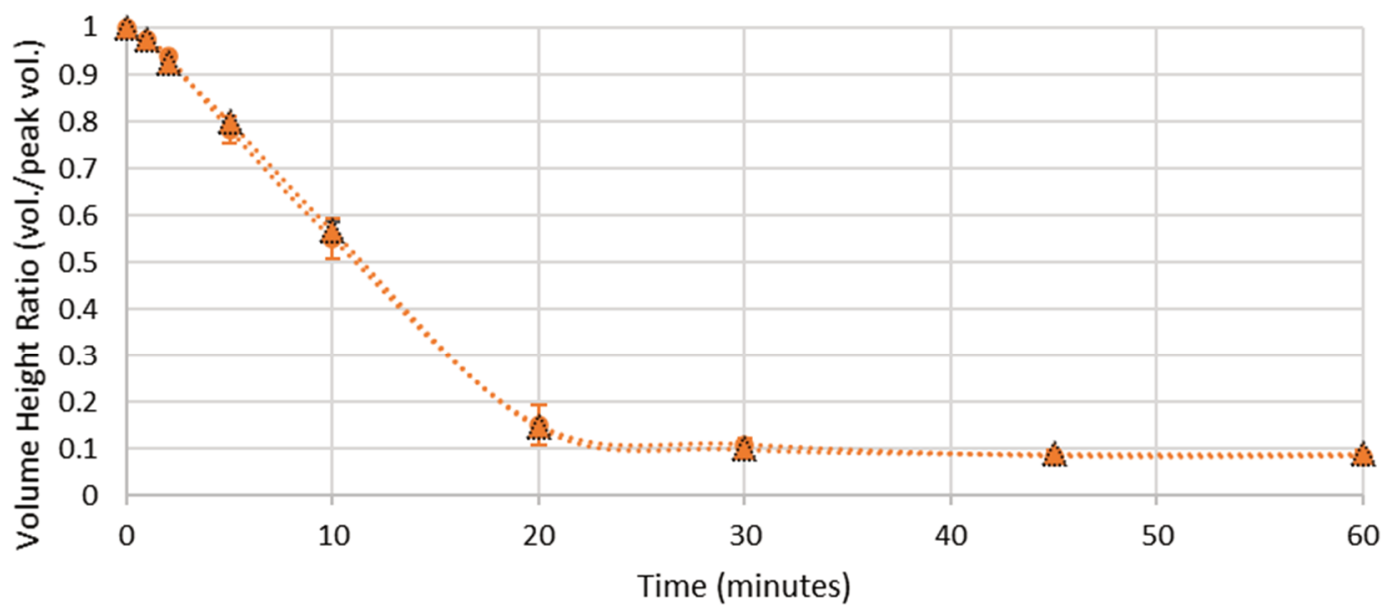

...... MBI 4.6, 0.5\% Solids, $\mathrm{CaCl}_{2} \cdot 2 \mathrm{H}_{2} \mathrm{O} \quad \cdots \cdot \cdots \mathrm{MBI} 13.3,0.5 \%$ Solids, $\mathrm{CaCl}_{2} \cdot 2 \mathrm{H}_{2} \mathrm{O}$

Figure 5 Average volume height ratio versus time. Preliminary stage $0.5 \%$ solids, $\mathrm{CaCl}_{2} \cdot 2 \mathrm{H}_{2} \mathrm{O}$, settling tests

Table 3 and Figures 4-6 show that solids content is also an important factor, where the $0.5 \%$ solids tests settled much faster than the $25 \%$ solids tests by a factor of three times faster for coagulating chemistry, whereas the $0.5 \%$ solids tests were $3-11$ times faster than $25 \%$ solids tests for dispersive water chemistry. In addition, for the initially $25 \%$ solids tests (Figure 7), the highest percent solids achieved at the end of testing (for MBI 4.6, coagulating chemistry) was $27.0 \%$ solids, and $25.8 \%$ (for MBI 4.6, dispersive chemistry). Whereas Figures 8 and 9 show the highest \% solids achieved at the end of test, for $0.5 \%$ solids tests was $6 \%$ solids (for $\mathrm{MBI} 4.6$, coagulating chemistry) and $0.6 \%$ solids (for $\mathrm{MBI} 4.6$ and 13.3 , dispersive chemistry). The $25 \%$ solids tests have interactions that exist between the particles creating a hindered settling or consolidating environment as opposed to a free-settling environment as is indicative in Figures 4 and 7. 


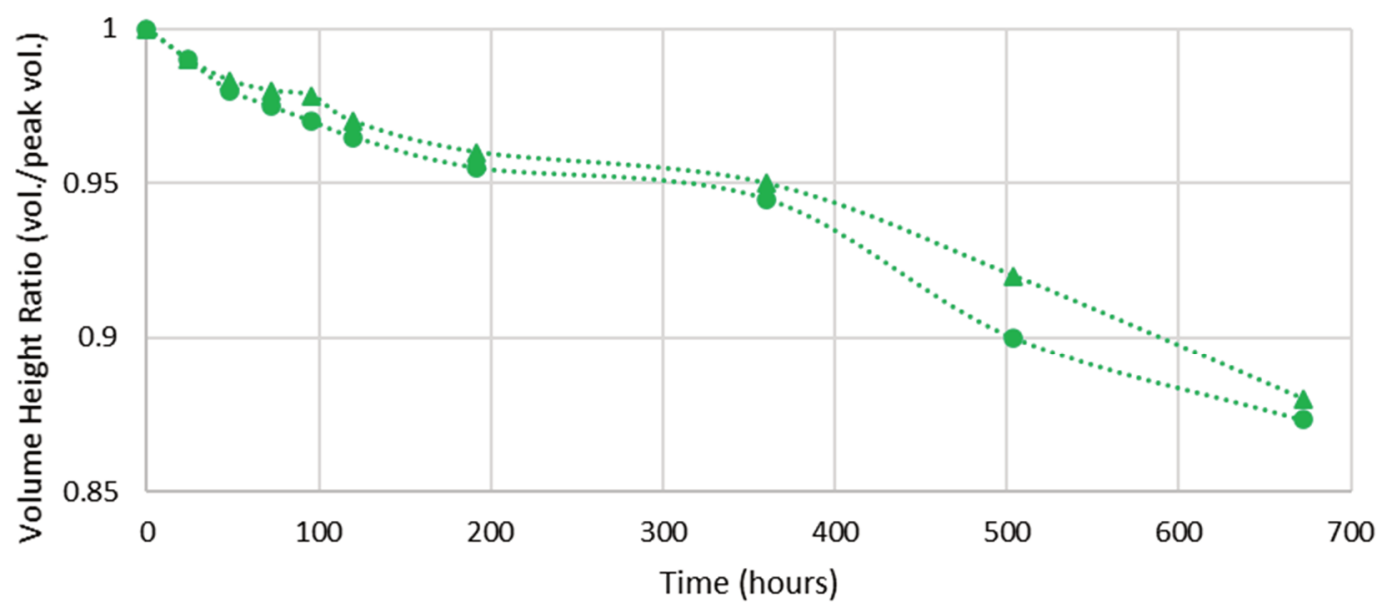

$\cdots \cdot \mathrm{MBI} 4.6,0.5 \%$ Solids, $\mathrm{NaCl} \quad \cdots . . . \mathrm{MBI} 13.3,0.5 \%$ Solids, $\mathrm{NaCl}$

Figure 6 Average volume height ratio versus time. Preliminary stage $0.5 \%$ Solids, $\mathrm{NaCl}$, settling tests

The third factor that influenced settling was the MBI of the sample (Table 3 and Figures 4 to 9). For the dispersive chemistry, at $25 \%$ solids, and an $\mathrm{MBI}$ of 4.6 , the ISR was three times more than the $\mathrm{MBI}$ of 13.3. For the coagulating chemistry, at $25 \%$ solids, and an MBI of 4.6 , the ISR was faster than the MBI of 13.3 by a factor of one. The lower the MBI, the faster the settling. However, it should be noted as is apparent from Figures 5, 6, 8 and 9 there was virtually no difference in settling rate between an MBI of 4.6 and 13.3, for both dispersive and coagulating water chemistries at a $0.5 \%$ solids level.

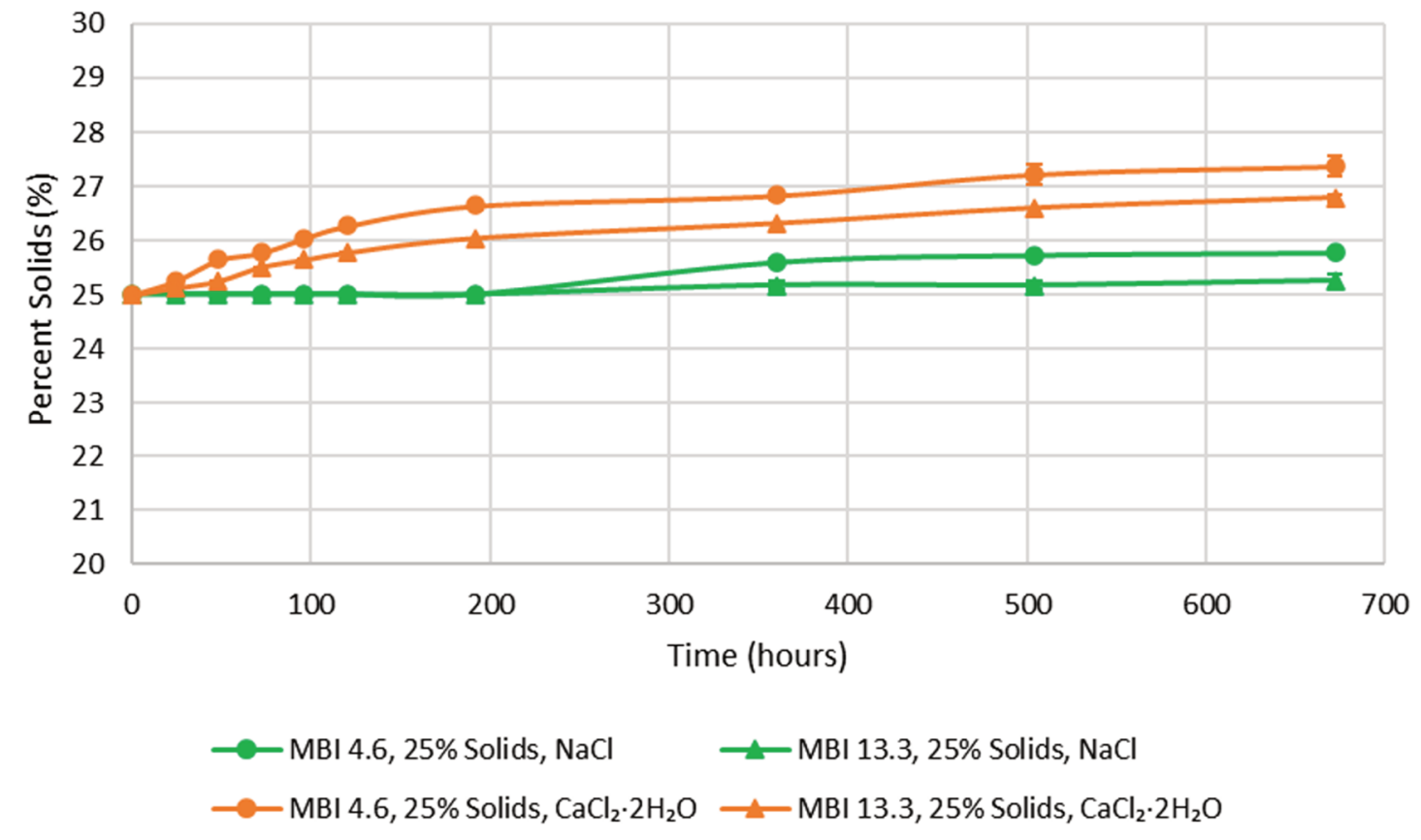

Figure 7 Average percent solids versus time. Preliminary stage $25 \%$ solids, both chemistries, settling tests 


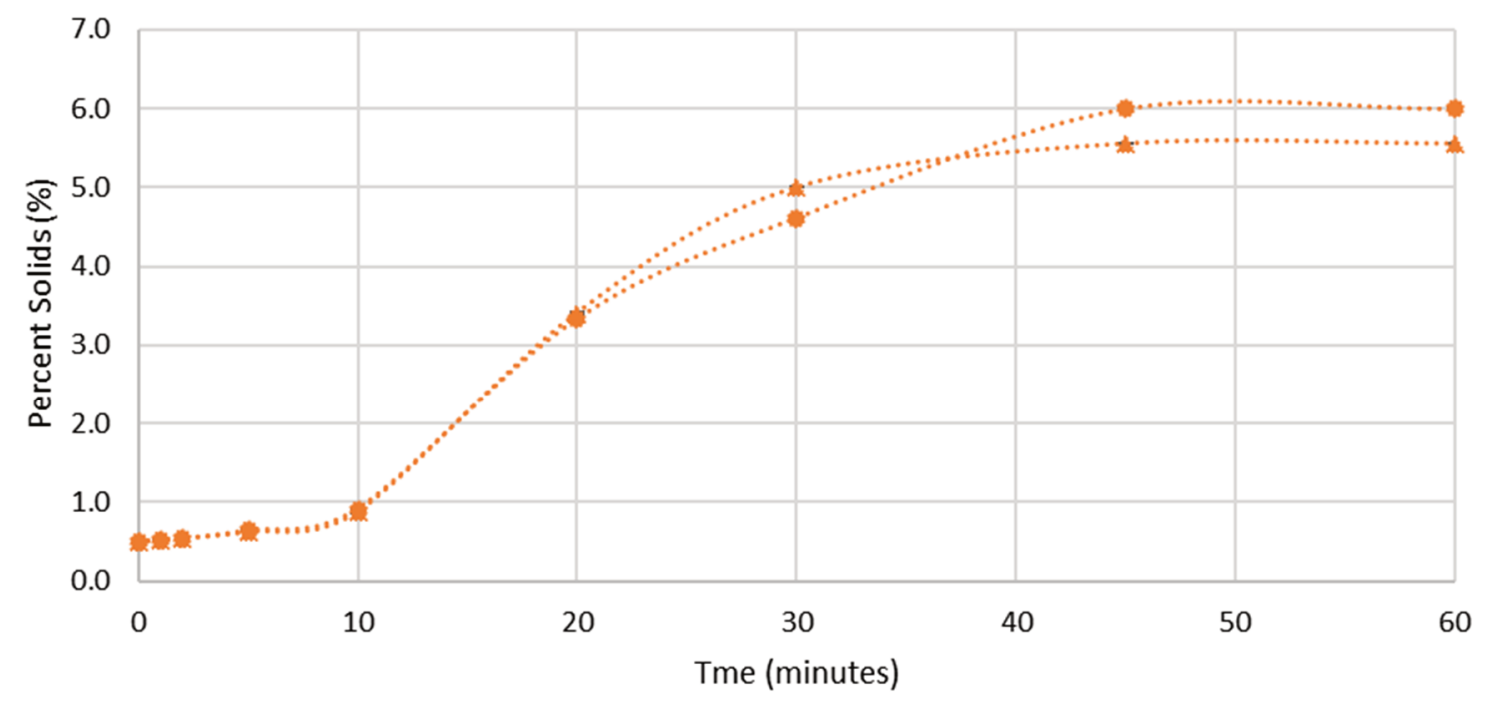

$\cdots \cdot \cdots \mathrm{MBI} 4.6,0.5 \%$ Solids, $\mathrm{CaCl}_{2} \cdot 2 \mathrm{H}_{2} \mathrm{O} \quad \cdots \cdot \mathrm{MBI} 13.3,0.5 \%$ Solids, $\mathrm{CaCl}_{2} \cdot 2 \mathrm{H}_{2} \mathrm{O}$

Figure 8 Percent solids versus time. Preliminary stage $0.5 \%$ solids, $\mathrm{CaCl}_{2} \cdot 2 \mathrm{H}_{2} \mathrm{O}$, settling tests

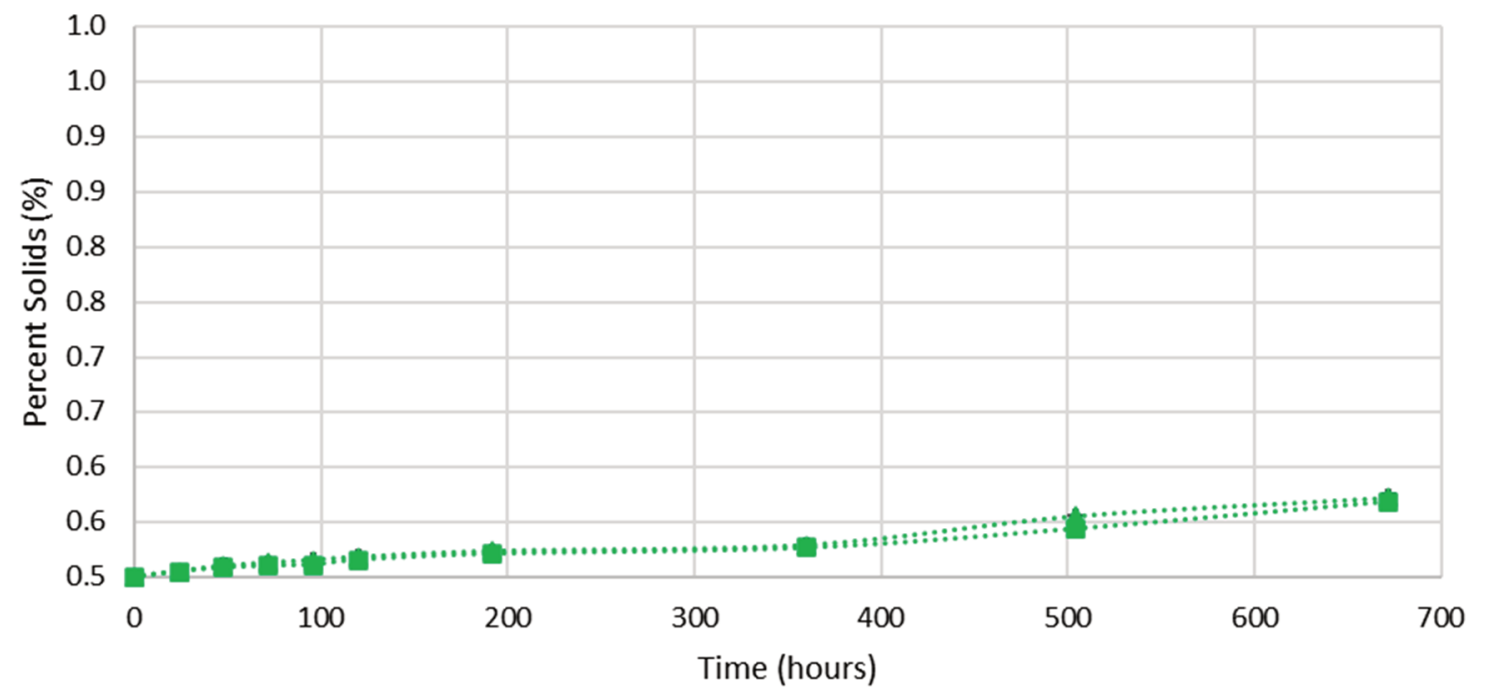

......... MBI 4.6, 0.5\% Solids, $\mathrm{NaCl}$

.. MBI 13.3, 0.5\% Solids, $\mathrm{NaCl}$

Figure 9 Average percent solids versus time. Preliminary stage $0.5 \%$ solids, $\mathrm{NaCl}$, settling tests

\subsection{Preliminary stage: SRF test}

The data from the preliminary stage SRF tests, as outlined by Table 4 and Figures 10 and 11, show that the SRF tests follow the same trends as shown in the settling tests. As with the settling tests, the biggest factor in the rate of water release is the water chemistry, followed by the solids content, and finally by the MBI. It has been reported water chemistry (i.e. salt composition) can affect the surface charges of clay particles (Kumar et al. 2017; Mohammed et al. 2021). Unlike settling tests which can take weeks to measure appreciable settling in high clay, dispersed systems, the SRF was able to measure these effects in hours. This means the linear portion of the SRF curve is a useful comparison test for comparing initial dewatering between samples. 
Table 4 Preliminary stage: SRF test data relative comparison to most resistance in a given circumstance (in orders of magnitude and factors)

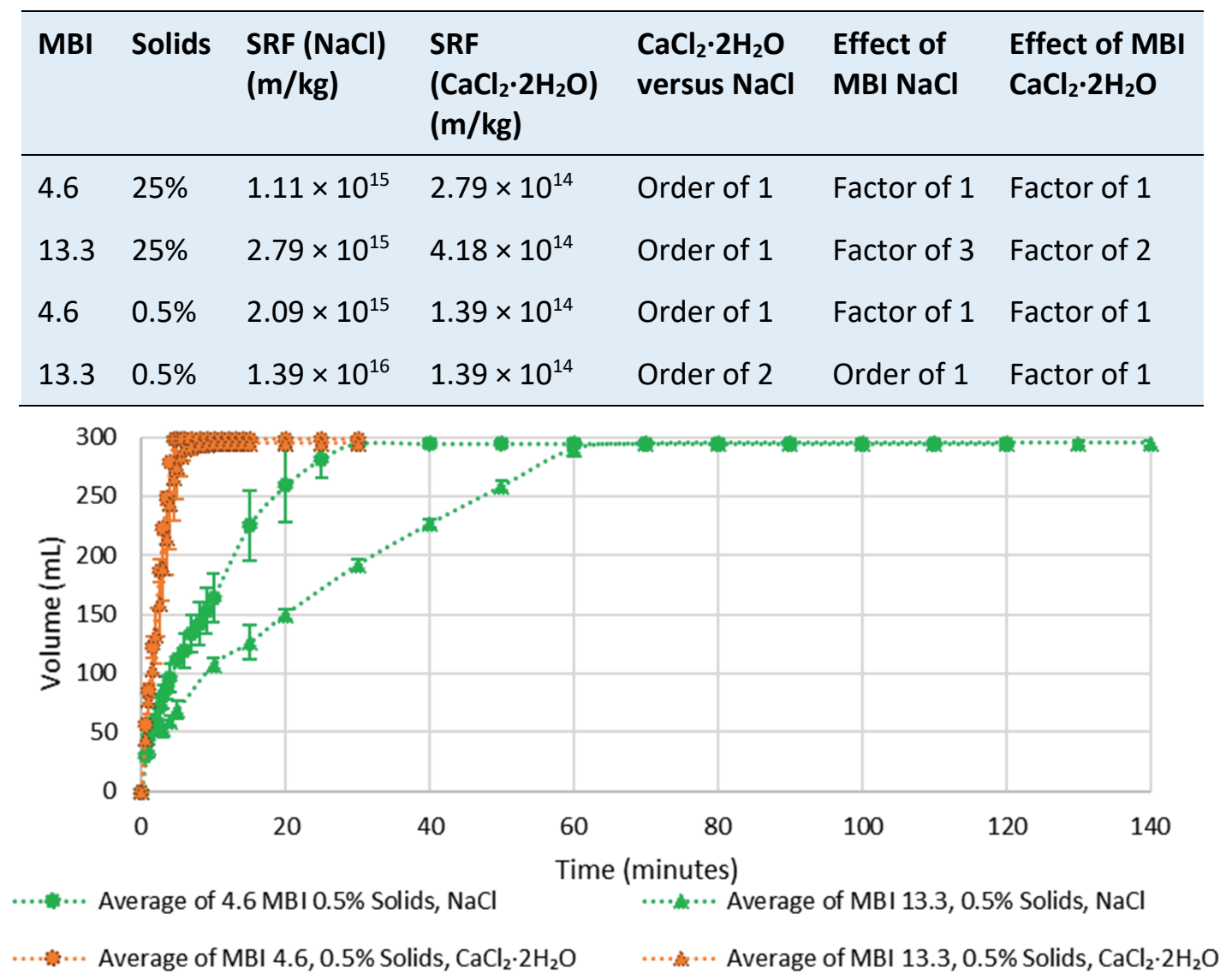

Figure 10 Average volume $(\mathrm{mL})$ versus time (minutes) for $0.5 \%$ solids (preliminary stage: SRF)

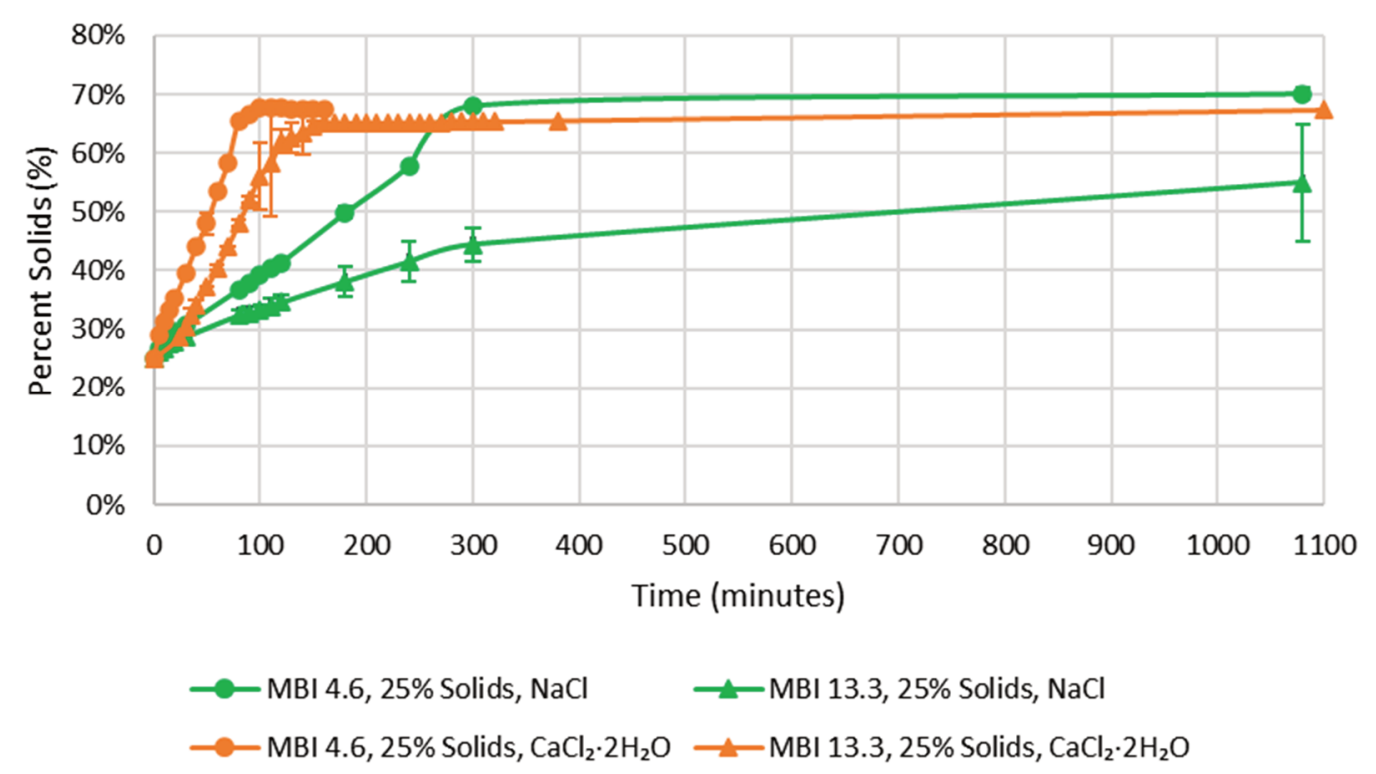

Figure 11 Average solids content (\%) of filtered cake versus time ( $\min$.$) for 25 \%$ solids (preliminary stage: SRF)

The SRF test may also provide insight into the consolidation impacts by evaluating the degree to which water is released at the plateau. In low solids content samples, there was effectively no consolidation required in the sample as the dilute nature of the samples meant that the water could freely drain as there was only $1.5 \mathrm{~g}$ of solids present in the initial $300 \mathrm{~g}$ sample so no appreciable filter cake built up. 
On the other hand, the $25 \%$ solids samples differences were noted in the solids content where the dewatering rate dramatically slowed/stalled. This was at $~ 69 \%$ solids for the two MBI 4.6 samples, and around $\sim 65 \%$ solids for the $\mathrm{MBI} 13.3$ with $\mathrm{CaCl}_{2} \cdot 2 \mathrm{H}_{2} \mathrm{O}$. The $\mathrm{MBI} 13.3$ with $\mathrm{NaCl}$ demonstrated a slow down around $45 \%$ solids but did not ever truly plateau. The test was stopped after 1,200 minutes as the rate of change in the release water was approaching the rate of evaporation from the graduated cylinder. The change in slope likely indicates that a layer with lower hydraulic conductivity has formed on the filter and that water released by the bulk sample now also has to travel through this second layer.

\subsection{Preliminary versus second stage}

The purpose of the second stage of testing was to evaluate whether the SRF could be used to assess the impact of polymer addition. Figure 12 shows that the addition of polymer BASF 1176 with $\mathrm{CaCl}_{2} \cdot 2 \mathrm{H}_{2} \mathrm{O}$ chemistry (purple line) resulted in a faster result; the test finishes in 140 minutes with polymer as compared to 160 minutes with no polymer added (blue line). In this case, the percent solids increase was not meaningful when a polymer is used (only a negligible $0.63 \%$ increase) but the duration to reach the plateau decreases by 20 minutes when polymer BASF 1176 is used. However, the use of this polymer with $\mathrm{NaCl}$ chemistry (orange line) resulted in slower results; the test finishes in 1,080 minutes with no polymer as compared to 2,720 minutes with polymer 1176 added (red line). The maximum percent solids increased from 52.8 to $66.99 \%$. In this case, addition of polymer shifted the solids content at which a slowdown in release was observed, from $45 \%$ solids to $~ 55 \%$ solids.

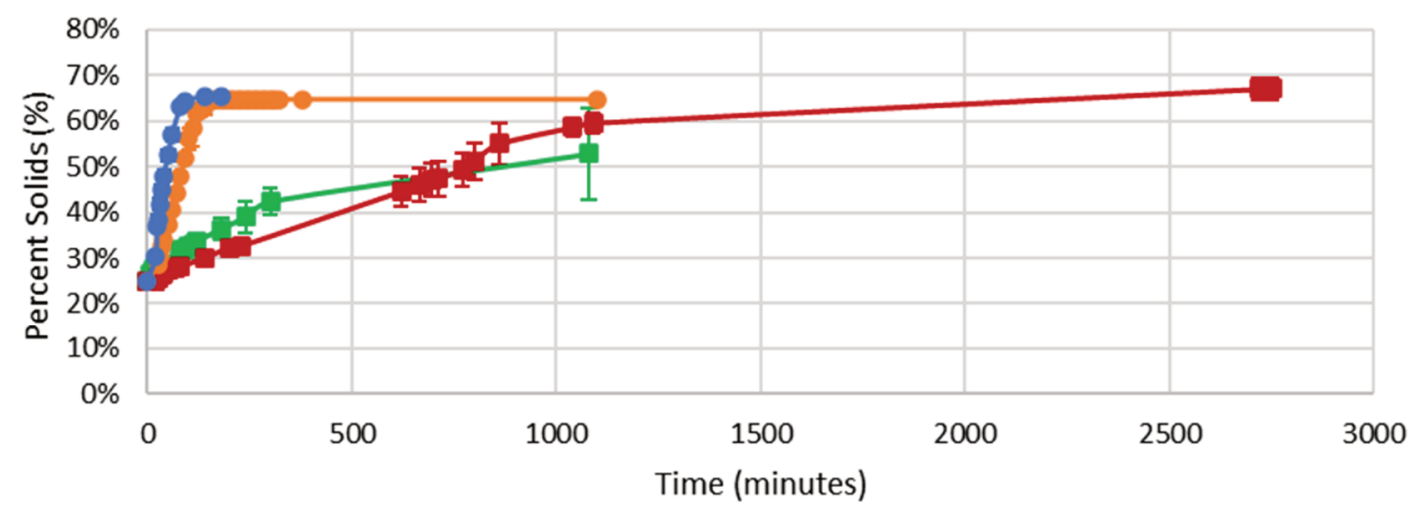

$-\mathrm{MBI} 13.3,25 \%$ Solids, $\mathrm{NaCl}$, No Polymer
$-\mathrm{MBI} 13.3,25 \%$ Solids, $\mathrm{CaCl}_{2} \cdot 2 \mathrm{H}_{2} \mathrm{O}$, No Polymer

-MBI 13.3, 25\% Solids, NaCl, Polymer 1176 $\longrightarrow$ MBI 13.3, 25\% Solids, $\mathrm{CaCl}_{2} \cdot 2 \mathrm{H}_{2} \mathrm{O}$, Polymer 1176

Figure 12 Average solids content (\%) of filtered cake versus time (min.) comparing no-polymer with low-mid molecular weight anionic polyacrylamide/polyacrylate copolymer (1176) at MBI 13.3, and $25 \%$ solids (second stage: SRF)

As far as testing is concerned, it is important to consider visual elements as well as patterns in the data. Regarding $\mathrm{NaCl}$ chemistry settling tests, as it is expected with a dispersed non-coagulating system, a cloudy interface layer was observed. This layer made it hard to read the interface between the sediment and water. Conversely, the $\mathrm{CaCl}_{2} \cdot 2 \mathrm{H}_{2} \mathrm{O}$ chemistry showed no such cloudiness as shown in the figures below for the $0.5 \%$ solids level; the same was true for the $25 \%$ solids level. The effect is apparent for settling tests as shown in Figure 13. 


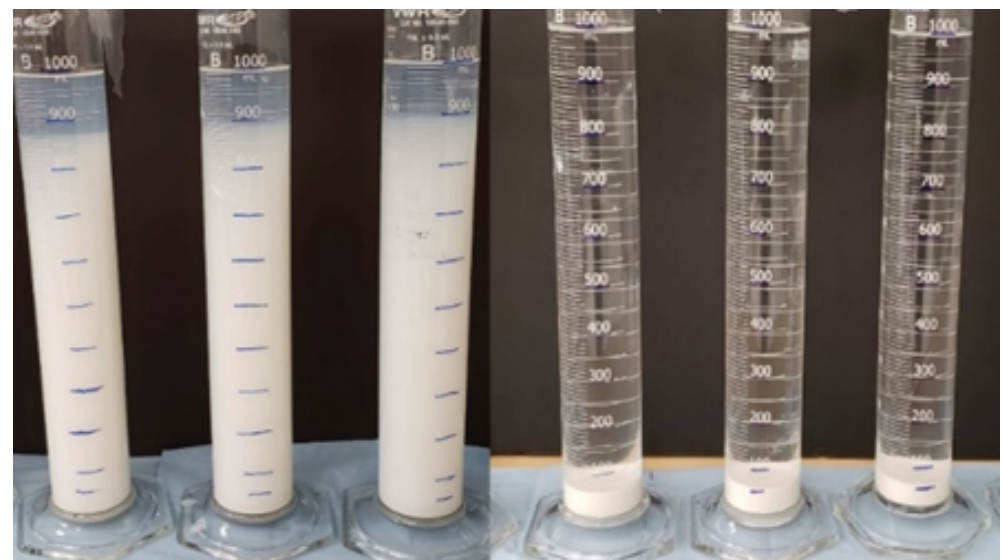

(a)

(b)

Figure 13 Settling test comparison of interface layers at $0.5 \%$ solids level. (a) Dispersive chemistry; (b) Coagulating chemistry. Source Qureshi et al. (2019)

Figure 14 shows a comparison of the SRF filtrate between (a) dispersive and (b) coagulating water chemistries. Similar to settling tests, with the preliminary stage SRF data, $\mathrm{CaCl}_{2} \cdot 2 \mathrm{H}_{2} \mathrm{O}$ chemistry showed colourless water coming out of the SRF into the graduated cylinders, while the $\mathrm{NaCl}$ chemistry showed cloudy water coming out. This effect was seen at both the 0.5 and $25 \%$ solids level and continued into the second stage of testing.

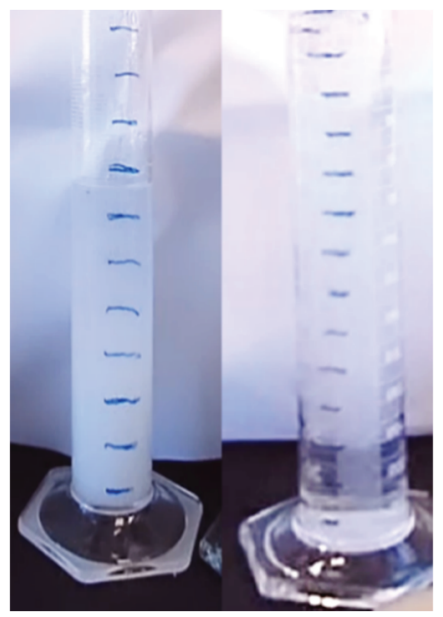

(a)

(b)

Figure 14 (a) Cloudy SRF filtration water for $\mathrm{MBI} 13.3,0.5 \%$ solids, $\mathrm{NaCl}$ (dispersive water chemistry); (b) Clear SRF filtration water for $\mathrm{MBI} 13.3,0.5 \% \mathrm{CaCl}_{2} \cdot 2 \mathrm{H}_{2} \mathrm{O}$ (coagulating water chemistry). Source: Qureshi et al. (2019)

This observation indicates that the SRF is showing the same visual trends as the settling tests, but faster, i.e. within 24 hours rather than the four weeks required for settling tests. Also, the science supports these visual observations, as coagulation occurs with $\mathrm{CaCl}_{2} \cdot 2 \mathrm{H}_{2} \mathrm{O}$ chemistry, while most (if not all) solids are captured. Whereas $\mathrm{NaCl}$ performs in the opposite manner, as it is dispersive chemistry (Vietti 2018). Interestingly, the flocculated samples between the two water chemistries had distinct differences. The flocs with coagulating chemistry were well formed and the release water was clear, whereas the dispersive chemistry flocculated samples were showing cloudy water release and flocs were smaller (Figure 15). 


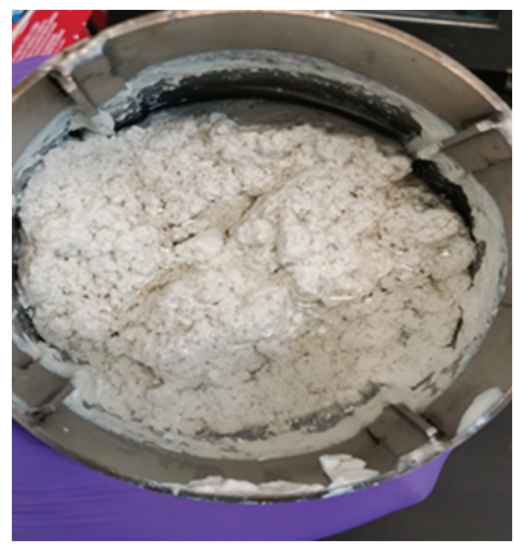

(a)

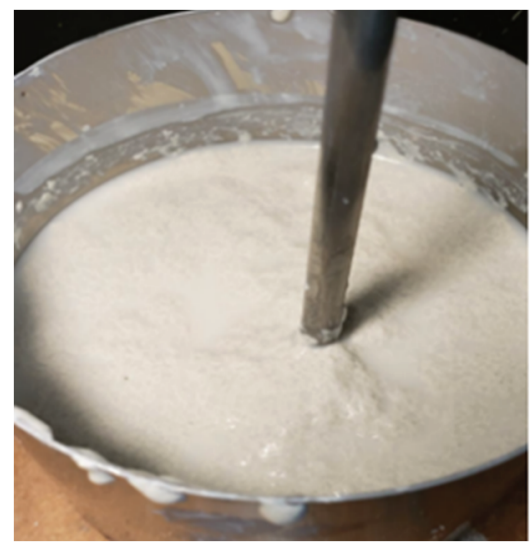

(b)

Figure 15 (a) Flocs for MBI 13.3, 25\% solids with calcium chloride chemistry (Qureshi et al. 2019); (b) Flocs for MBI 13.3, 25\% solids with sodium chloride chemistry (Qureshi et al. 2019)

Moreover, the filter cakes from between the two water chemistries also presented distinct differences. Where the $\mathrm{NaCl}$ water chemistry filter cakes were flexible and rolled or bent into shape upon trying to break it in half, the $\mathrm{CaCl}_{2} \cdot 2 \mathrm{H}_{2} \mathrm{O}$ water chemistry filter cake, although initially hard, presented a brittle texture as is seen in Figure 16.

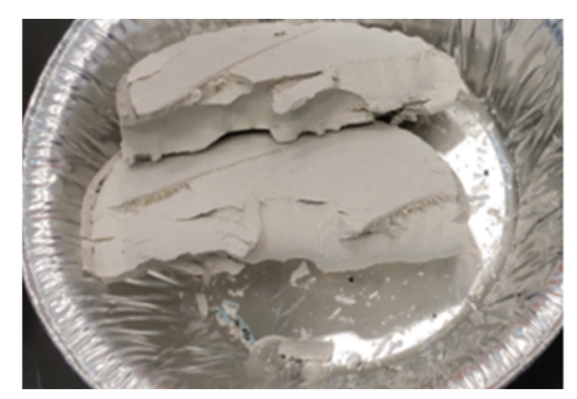

(a)

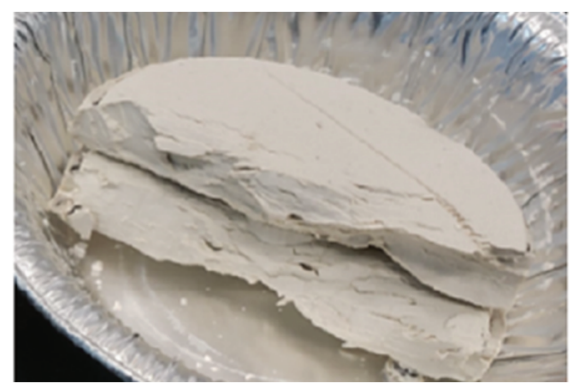

(b)

Figure 16 (a) Filter cake for MBI 13.3, 25\% solids, sodium chloride chemistry (Qureshi et al. 2019); (b) Filter cake for MBI 13.3, 25\% solids, calcium chloride chemistry (Qureshi et al. 2019)

\subsection{Oil sands testing}

The objective of the third phase of testing was to apply the developed test to FFT that had been exposed to various treatments to see if key differences in their response could be observed. To this end, FFT was treated with different additives: SNF polymer A3338 at optimal dosage (1,360 g/tonne solids), lime (6,500 ppm), and the combination of A3338 and lime. Lime was added to FFT as a slurry with a concentration of 5 wt.\% (mass of lime/mass of water) in deionised water. The treated FFT samples were pressed with the modified filter press setup at 20 psi together with the untreated FFT as a control test. The 20 psi of gas pressure was used as it is equivalent to about $5 \mathrm{~m}$ of sand overburden. All three types of treatment greatly increased the filtrate flow rate compared with untreated FFT indicating the significant increase in dewatering performance of treated FFT (Figure 17). All final solids contents of the compressed cakes of both treated and untreated FFT samples were $\sim 60 \mathrm{wt} . \%$ at which point the water release rate became negligible, indicating a change in dewatering mechanism - possibly the point where all the freely draining water has been removed. The treatment of the combination of A3338 and lime achieved the final stage in the shortest filter press time ( 180 minutes), followed by the treatment of lime ( 270 minutes). Untreated FFT required about 1,900 minutes to achieve the final stage, 10 times longer than the same FFT treated by the combination of A3338 and lime under the same filter press condition. 


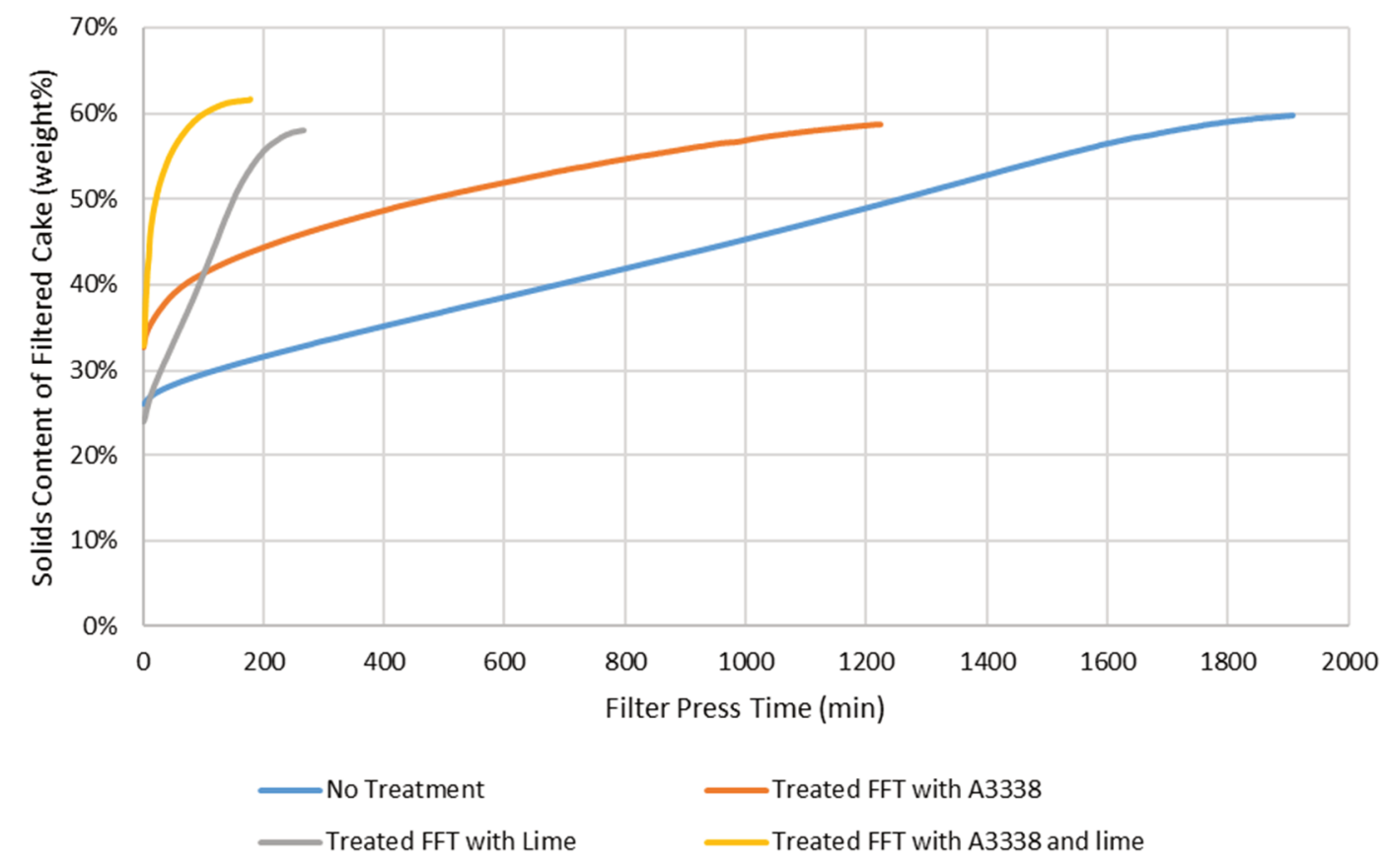

Figure 17 Filter press testing curves of untreated FFT and treated FFT with polymer A3338 at optimal dosage $(1,360 \mathrm{~g} /$ tonne), lime at the dosage of $6,500 \mathrm{ppm}$, and the combination of A3338 and lime

\section{Conclusion}

Overall, the research from the preliminary stage of testing shows that the SRF test is a viable tool that provides results that make sense based on the DLVO theory. It also shows similar trends to the settling test indicating that factors such as water chemistry, percent solids, and $\mathrm{MBI}$ all can be differentiated resulting in the determination of factors that can play a crucial role in dewatering. The second stage of testing, where a polymer versus a non-polymer is compared suggests that the SRF can also be used for screening technologies to see if they are really effective or not and in what circumstances (coagulating or dispersive water chemistry, higher or lower percent solids, higher or lower MBIs). A relatively quick SRF test can give this essential information in a fraction of time. Additionally, second stage analysis suggests that using the SRF to screen polymer addition can show important results including the enhancement of the rate of dewatering. Finally, the SRF test can be used as an initial assessment tool for comparing polymers/chemicals before moving to other options, such as settling tests. In the final stage of the study, the dewatering performance of the oil sands tailings with different types of treatments was characterised using the modified filter press. The modified filter press was able to differentiate between different FFT treatments; in this case, finding the combination of flocculation and coagulation was superior to the other treatments applied to FFT. Based on the modified SRF data, the FFT treated with the combination of flocculant and lime is also expected to have a faster settling rate than other treatments. Based on the work performed to date, the modified filter press shows every indication that it could provide an indicator of long-term consolidation information when compared to large strain consolidation and other consolidation techniques. Future work is planned to study this claim. Through this work, the team plans to use the modified SRF test to further understand the properties of oil sands tailings ponds, and conditions therein.

\section{Acknowledgement}

The completion of this work could not have been possible without the participation and assistance of the following individuals and bodies.

Mr Ivan Scheverman, Mr Hadi Temraz, Mr Stephen Ashworth, Dr David Schmaus, Dr Joseph Varughese, Mr Kessmar Manahan, the NAIT Applied Research Centre for Oil Sands Sustainability, and the Bachelor of Technology Program at NAIT. 


\section{References}

Alberta Energy Regulator 2017, Directive 085: Fluid Tailings Management for Oil Sands Mining Projects, Alberta Energy Regulator, Calgary, viewed 20 July 2021, https://www.aer.ca/documents/directives/Directive085.pdf

Alberta Energy Regulator (2019), Tailings, Alberta Energy Regulator, Calgary, viewed 20 July 2021, https://www.aer.ca/providinginformation/by-topic/tailings

Canadian Association of Petroleum Producers n.d., Canada's Oil Sands, Canadian Association of Petroleum Producers, Calgary, viewed 20 July 2021, https://www.canadasoilsands.ca/en/explore-topics/tailings-ponds

Canada's Oil Sands Innovation Alliance n.d.-a, Accelerated Dewatering, Canada's Oil Sands Innovation Alliance, Calgary, viewed 20 July 2021, https://www.cosia.ca/initiatives/tailings/projects/accelerated-dewatering

Canada's Oil Sands Innovation Alliance n.d.-b, Tailings, Canada's Oil Sands Innovation Alliance, Calgary, viewed 20 July 2021 , https://www.cosia.ca/initiatives/tailings

Canada's Oil Sands Innovation Alliance, Unified Fines Method for Minus 44 Micron Material and for Particle Size Distribution, viewed 20 July 2021, Canada's Oil Sands Innovation Alliance, Calgary, https://www.cosia.ca/uploads/documents/id18/ COSIA\%2OFMWG\%20Fines\%20Method\%20February\%202016.pdf

Dean, EW \& Stark, DD 1920, 'A convenient method for the determination of water in petroleum and other organic emulsions', Journal of Industrial and Engineering Chemistry, vol. 12, no. 5, pp. 486-490, https://doi.org/10.1021/ie50125a025

Environmental Business Specialists n.d., 30-Minute Settling Test of Activated Sludge Systems, Environmental Business Specialists, Mandeville, viewed 20 July 2021, https://www.ebsbiowizard.com/30-minute-settling-test-of-activated-sludge-systems-2-968

Government of Alberta 2015, Lower Athabasca Region: Tailings Management Framework for the Mineable Athabasca Oil Sands, viewed 20 July 2021, https://open.alberta.ca/dataset/962bc8f4-3924-46ce-baf8-d6b7a26467ae/resource/7c49eb63-751b49fd-b746-87d5edee3131/download/2015-larp-tailingsmgtathabascaoilsands.pdf

Guang, R, Quintero, A \& Longo, S 2016, 'Evaluation of laboratory scale of tailings thickening test', in S Barrera \& R Jewell (eds), Paste 2016: Proceedings of the 19th International Seminar on Paste and Thickened Tailings, Gecamin, Santiago.

Kaminsky, H 2014, 'Demystifying the methylene blue index', in H Kaminsky (eds), Proceedings of the 2014 Oil Sands Tailings Conference, Suncor Energy Inc., Calgary.

Kumar, N, Anderson, MP, van den Ende, D, Mugele, F \& Siretanu, I 2017, 'Probing the surface charge on the basal planes of kaolinite particles with high-resolution atomic force microscopy', Langmuir, vol. 33, pp. 14226-14237, http://dx.doi.org/ 10.1021/acs.langmuir.7b03153

Li, Y, Kaminsky, H, Romaniuk, N \& Tate, M 2018, 'Filter press modification to assess dewatering performance of fluid fine tailings', Proceedings of the International Oil Sands Tailings Conference 2018, University of Alberta, Edmonton.

Lu, Y 2016 Origin of Specific Resistance to Filtration and Relationship Between SRF and CST, blog post, viewed 20 July 2021 , https://lukeworkblog.blogspot.com/2016/05/assignment-origin-of-specific.html

Mohammed, I, Shehri, DA, Mahmoud, M, Kamal, MS \& Alade, OS 2021, 'A surface charge approach to investigating the Influence of oil contacting clay minerals on wettability alteration', ACS Omega, vol. 6, no. 199, pp. 12841-12852, https://doi.org/ 10.1021/acsomega.1c01221

Natural Resources Canada 2016, Oil Sands: Tailings Management, viewed 20 July 2021, https://www.nrcan.gc.ca/energy/ publications $/ 18752$

Ofite 2013, API Filter Press, Multi-Unit, apparatus, viewed 20 July 2021, http://www.ofite.com/publications/instructions/138-14040-instructions/file

Ofite 2021, Filter Paper, Whatman \#50, 3 1/2" (9 cm), 2.7 um, Package of 100, equipment, https://www.ofite.com/products/ product/569-filter-paper-whatman-50-3-1-2-9-cm-2-7-um-package-of-100

Omotoso, O \& Morin, M 2008, Methylene Blue Procedure: Dean Stark Solids, CanmetENERGY, Devon.

Patterson, AJC 2004, 'High density slurry and paste tailings, transport systems', Proceedings of the International Platinum Conference 'Platinum Adding Value', The South African Institute of Mining and Metallurgy, Johannesburg, https://www.saimm.co.za/ Conferences/Pt2004/159_Paterson.pdf, pp. 159-166.

Qureshi, TH, Scheverman, RI \& Temraz, H 2019, Specific Resistance to Filtration for Oil Sands Tailings Consolidation, paper presented at NAIT BTech Capstone Showcase 2019, Edmonton.

Sadighian, A, Revington, A, Kaminsky, H, Moyls, B, Li, Y \& Omotoso, O 2018, 'A new protocol to assess the quality of tailings flocculation/coagulation: A collaboration to improve tailings treatment at Suncor Energy', Proceedings of the Sixth International Oil Sands Tailings Conference.

SNF Floerger n.d., Water Soluble Polymers, SNF Floerger, Andrézieux-Bouthéon, http://www.snfcanada.com/attachments/ Water_Soluble_Polymers_E.pdf

Suncor n.d., Reclamation, viewed 20 July 2021, https://sustainability.suncor.com/en/environment/reclamation

United States Geological Survey n.d., Water Density, viewed 20 July 2021, United States Geological Survey, Reston, https://www.usgs.gov/special-topic/water-science-school/science/water-density?qt-science_center_objects=0\#qtscience_center_objects

Vietti, A 2018, 'Clay-water interactions', in J Stucki, O Omotoso \& D Hockley (eds), Introduction to Oil Sands Clays, The Clay Minerals Society, Chantilly, pp. 64-69.

Zink, D 2019, 5 Factors that Influence Filter Press Cake Percent Solids and Percent Moisture, blog post, viewed 20 July 2021 , https://www.mclanahan.com/blog/5-factors-that-influence-filter-press-cake-percent-solids-and-percent-moisture 